\title{
NUP98/ADD3 Fusion Gene
}

National Cancer Institute

\section{Source}

National Cancer Institute. NUP98/ADD3 Fusion Gene. NCI Thesaurus. Code C99453.

A fusion gene that results from a chromosomal translocation $t(10 ; 11)(q 25 ; p 15)$ which fuses the first half of the NUP98 gene to the ADD3 gene. This rearrangement is associated with T-cell acute lymphoblastic leukemia. 